\title{
The Construction of Teacher Identity in Education for Sustainable Development:
}

\section{The Case of Chinese ESP Teachers}

\author{
Wenjin Qi ${ }^{1,2}$, Nadezda Sorokina ${ }^{2} \&$ Yan Liu ${ }^{1}$ \\ ${ }^{1}$ Yuncheng University, Yuncheng, China \\ ${ }^{2}$ Woosong University, Daejeon, South Korea \\ Correspondence: Wenjin Qi, College of Foreign Languages, Yuncheng University, China.
}

Received: November 22, 2020

Accepted: December 10, $2020 \quad$ Online Published: December 15, 2020

doi:10.5430/ijhe.v10n2p284

URL: https://doi.org/10.5430/ijhe.v10n2p284

\begin{abstract}
As the education for sustainable development (ESD) has been advocated in diverse educational contexts, increasingly more attention has been paid to facilitate teachers as the promoters of such educational practice in higher education. Yet, less sufficient research has focused on the ESP (English for Specific Purposes) teachers, who are regarded as the pioneers of ESD practice, and their professional development. This study aims to promote teacher professional development in the area of ESD practice by investigating the identity construction of eight ESP teachers from a northern Chinese university. Drawing on a model of ESP teacher identity, the authors conducted life-history interviews concerning the five frames of identity construction. The results reveal a complex picture of ESP teachers' professional identity construction. It is revealed that a majority of participants claimed a sense of achievement in their teaching of ESP skills and sustainability competences in graduates for the local socioeconomic development. However, their professional identification is undermined by such factors as the marginalization of ESP as a legitimate discipline, lack of acknowledgement of ESD in curriculum design, and teachers' professional insecurity resulted from their professional incompetence and low academic status. This study provides a new and innovative perspective on the issue of ESD development in higher education.
\end{abstract}

Keywords: teacher identity, education for sustainable development, ESP teachers, higher education, professional development, China

\section{Introduction}

The year of late 2019 has witnessed the outbreak of global pandemic of COVID-19, threatening people's health and lives all over the whole world. It has set people to reflect their relationships with the nature. And the issue of sustainable human development has been given unprecedented attention and emphasis in all fields. Being the most fundamental field, education for sustainable development (ESD) equips students with sustainable development principles and essential skills to solve problems in post-pandemic era. It is particularly true of universities in higher education. As university teachers are playing a decisive role in implementing educational practices, the construction of their professional identity is worth all the more academic attention.

This study selects a unique group of university ESP (English for Specific Purposes) teachers as its participants, who are highly motivated to integrate sustainability education into their teaching practice. The construction and complexity of their identity are illustrated through the narratives in the interview. It examines the impact of ESD principles and practices on the teacher professional identity development as well as identifies obstacles and crises in teacher identity construction in order to facilitate their professional development in the fields of diverse disciplines and certain innovative educational practice.

\subsection{A Brief Overview of ESD}

Education has been playing a critical role in sustainable development as in instilling students with a heightened awareness to promote sustainability (UNESCO, 2014). Education for Sustainable Development refers to educational programs and experiences that are designed to allow people to acquire the knowledge, skills and values that are necessary to shape a sustainable future (Kishita, 2018). It is an educational process aiming at fostering participants' 
awareness and enhancing their understanding of sustainability issues as well as transforming their attitudes and behaviours regarding environment, society and economy so as to develop their competencies of participating in sociopolitical processes and moving their society towards sustainable development (Pappas et al., 2013; Leal Filho, 2015; Barth et al., 2016; Kalsoom et al., 2017). Sustainability education is considered to be a core discipline for disseminating sustainable development principles, and increased attention is dedicated to it and its applications (Cotton et al., 2007; Michalos, 2014; Olsson et al., 2015; Granados Sanchez \& Fredi, 2012). It is recommended by the United Nations in the Summit's Report (2002) to integrate ESD into educational systems. And educational institutions of all levels across the world have been encouraged to take a more active participation in the process towards sustainable development (Leal Filho, 2015).

Higher education is no exception in this regard. The importance of ESD has increased, particularly in higher education (Cotton et al., 2007). Since universities prepare future decision makers and professionals in large numbers, they have a great responsibility and considerable influence in leading society towards a sustainable future within a broader context (Leal Filho et al., 2018). And there is solid evidence that higher education institutions have been delivering a strong contribution to sustainable development as a whole, and to the implementation of education for sustainable development in particular (Leal Filho, 2010). Hence, it is highly suggested that higher education institutions should incorporate sustainability into their university culture (Sterling \& Witham, 2008) and perform a leadership role in developing forms of interdisciplinary education to diffuse knowledge, values, attitudes and behaviours that favour sustainability (Minguet et al., 2011).

In 2016, China launched a national plan for implementing Agenda 2030 oriented towards sustainable development. It has recognized the critical role that ESD plays in creating and developing a more sustainable society (Zhang, 2019). Correspondingly, the number of ESD-related research articles in the context of China has been growing significantly (Grosseck et al., 2019). However, despite its progress so far, ESD concept still has a long way to go and needs to become mainstream in more universities located in less academically-developed areas in China. It echos with similar phenomenon worldwide that there is only a small percentage of universities that adopted ESD (Leal Filho, 2015), and that there is little to show that ESD has been implemented in most universities (Holdsworth \& Thomas, 2015).

\subsection{A Brief Overview of ESP}

ESD is based on interdisciplinary and student-centered approaches (Mirjam Braßler, 2016) and it encourages critical thinking and future-oriented skills to develop better understanding of phenomena and construction of problems that need to be resolved in an integrated way (Varga et al., 2007). These features echo with the objectives of ESP teaching in higher education in the way that ESP teaching also encourages interdisciplinary thinking and allows students to use knowledge from different academic traditions to analyze situations and solve problems in new and creative ways. ESP courses emphasize the importance of interdisciplinary thinking and holistic insight due to its interconnectedness of environmental, social and economic issues (Warburton, 2003).

Moreover, ESP interdisciplinary research and praxis-oriented community engagement strengthen students' local and global knowledge of sustainability and cultivate sustainability-conscious talents for a wider range of industries. Therefore, ESP teaching is particularly relevant in the context of education for sustainability. It could be used as a pioneer approach to promote ESD in higher education.

Furthermore, ESP teacher is a unique group of university teachers for the reason that the purpose of ESP education is to enable college graduates to actively engage in an extensive range of international activities covering different disciplinary areas with their mastery of professional English (Tao \& Gao, 2018; Tweedie \& Johnson, 2018). The multifaceted and interdisciplinary features and praxis-oriented principle of ESP teaching align with that of sustainability (Jones, 2018). The graduates of ESP education, mastering knowledge and skills and critical thinking, are playing essential roles in promoting sustainable development in various industries that are crucial to societal sustainable development.

It is argued that the introduction of ESD concepts and the promotion of its practices in higher education could be used for inducing the professional development of academic staff (Biasutti et al., 2018). It is particularly true of ESP teachers in this case as ESP teachers have an advantage in mastering English as the international language, thus they have a high motivation and inclination to embrace new theory and practice, such as the concept of ESD, to improve their professional qualification. Hence, they are seen as a group of pioneers in promoting sustainability education in universities.

\subsection{A Brief Overview of Teacher Identity}

Teachers' professional identity, negotiated through experience and the sense that is made of that experience, provides 
a framework for teachers to construct their perceptions of themselves, their work and their place in society (Sachs, 2005). It is defined as a "continuously ongoing process" and is subject to changing educational environments (Beijaard et al., 2004, p. 122; Kubanyiova \& Crookes, 2016).

The past few decades witnessed an increasing interest in research study to comprehend and advocate teachers' identity development and its impact on their motivation to teach, the quality of their teaching, career commitment, overall wellbeing and career development (Beauchamp \& Thomas, 2009; Buchanan, 2015; Cross \& Hong, 2009; Day et al., 2013; Nichols et al., 2016; Schutz et al., 2007). Nevertheless, regardless of the progress and significance of our knowledge of teachers' identity development, researches are still in the early stages of understanding the formation of teacher identities, the factors that influence changes of identities, and the roles identity struggle and identity crisis play in the construction of teachers' identity (Schutz et al., 2018). The case of ESP teachers' identity formation in the context of sustainability education is among the randomly touched domains. It, therefore, presents a necessity of a holistic and subject-specific approach to explore ESP teachers' professional identity development.

In the context of ESD, a key factor in such practice lies in university teachers who apply sustainability criteria to their respective disciplines (Biasutti et al., 2017; Minguet et al., 2011). Through their educational activities and community engagements, university teachers contribute to a transformative process of preparing and developing graduates into future professionals in their respective professional domains who can find solutions to the pressing problems related to sustainable human development (Shephard, 2015). It is equally true of university ESP teachers in their teaching practice.

However, their ideas about and practice towards sustainability related to diverse subject areas are not always understood or appreciated, and it has left many teachers feeling confused about their subject-specific professional development in ESD, thus consequently causing certain barriers to the construction of ESP teachers' professional identity. What's worse, when asked to apply the complex and interdisciplinary approaches to ESD, teachers often convey doubts, unwillingness and even reject. Research reveals that these negative emotional responses have a critically debilitating effect on their teaching and sense of self during this process (Varga et al., 2007).

Educational research has widely examined the attitudes and beliefs of university teachers towards ESD (Minguet et al., 2011). Whereas, existing research rarely touched upon the attitudes and beliefs towards university teachers and their ESD practices. In their endeavor to implement ESD in higher education, ESP teachers have encountered misunderstanding, distrust or even prejudice from administrative staff, academic colleagues as well as students. All of them have generated negative feelings and emotions within teacher themselves, such as uncertainty, doubts and low self-perception, which resulted in many teachers themselves feeling confused about their professional identity (Day et al., 2005).

By situating ESP teachers in the context of a specific university in China, this study attempts to explore multiple subidentities of ESP teachers in order to disclose more contextualized facets of their professional identity. Eventually, it could expand the scope of teacher identity study and add additional perspective to ESD research body.

\section{Analytic Framework}

To explore the complex nature and multiple facets of teacher identity in continuously changing contexts, Pennington (2014) designed a Frames Model of teacher identity in the field of TESOL (Teaching English to Speakers of Other Languages). Since ESP teaching is one of the teaching approaches and orientations that have been associated with the TESOL field (Pennington, 2014), an adapted model was utilized to tap into the complex and changing characteristics of ESP teacher identity in their practice of sustainability education.

Pennington's (2014) model adopts a perspective of identity frames. It divides identity into two frames: practicecentered frames and contextual frames. Each sub-category of the two frames are considered to represent different facets of teacher identity. To be specific, there are five sub-frames under the category of practice-centered frame, namely, instructional, disciplinary, professional, vocational and economic frame.

The instructional frame refers to the public "role and persona" that a teacher enacts in classroom instruction (Pennington, 2014, p. 20); the disciplinary frame connects a teacher with the "knowledge and research" of a specific field (p. 20); the professional frame is manifested via teachers' individual characteristics shaped by their beliefs, knowledge and practices of a particular field; the vocational frame focuses on teachers' "commitment and attachment" to teaching as an "affective component" of their identity (p. 23); lastly, the economic frame discusses a teacher's "economic and academic position" in a specific field (p. 24).

Meanwhile, the five sub-frames are mediated by three contextual frames, namely, global, local and sociocultural context. The global frame represents global trends, such as the internationalization of education, the universal spread 
of English as a world language, and the interconnectedness of people induced by technology and internet. Teachers' global identity is built within these trends. The local frame relates to the departmental, institutional, community and national contexts in which teachers work and live. And the sociocultural frame includes the ethnic, racial, and gender identity of teachers as they position themselves socioculturally. These different contextual conditions in this model exert impact on teachers' professional practices as well as their identity construction.

Although the contextual frames have been recognized to have a more profound influence on the formation of teacher identity (Pennington, 2014), the coverage would be too broad and abstract to capture the different features of teacher identity in a specific and authentic institution. Besides, they are not the primary concerns of this study and bear limited relevance to the construction of ESP teacher identity. Therefore, this paper partially adopts the practice-centered frames of the model to best suit our research purpose. Since teacher identity is constructed beyond the confinement of the classroom, and it expands to include the institutions and communities in society (Johnson, 2006). In other words, the five sub-frames are mediated by such immediate contexts as the institutional and socio-economic contexts. Accordingly, this study also takes reference to the Tao \& Gao (2018)'s model of ESP teacher identity to create a refined model that fits the situation of our case (Figure 1). It attempts to examine the professional experiences of ESP teachers in their ESD practices in the context of a particular university in a northern Chinese city.

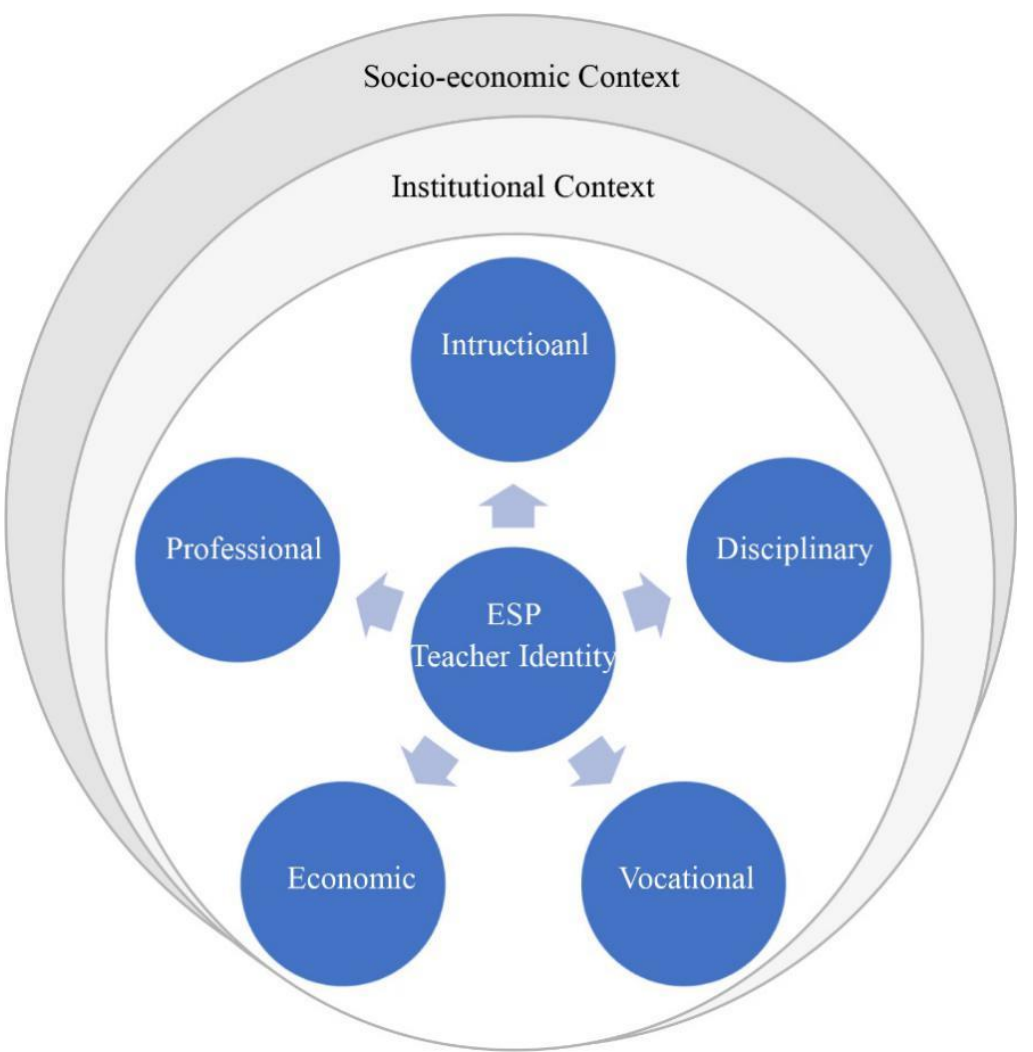

Figure 1. An adapted model of practice-centered frames of ESP teacher identity

Based on the above model, this study is conducted to address the following two research questions:

1) How did ESP teachers construct their teacher identities?

2) What are the sources of constraints in the construction of their ESP teacher identities?

\section{Methods}

Interviews were conducted aiming to identify patterns from the participants' professional and personal history. And the interview data that was verified as substantial and authentic sources was selected to answer the research questions proposed above.

\subsection{Research Context}

It is commonly practiced that English language subjects are compulsory courses for students of all majors in Chinese universities, yet these courses are provided by two departments which target two group of students. That is to say, the 
College English Department (later renamed as International Education School, hence IES hereafter) is responsible for teaching College English to non-English majors. Meanwhile, the Department of English, as a branch of Faculty of Foreign Languages (FFL), takes up the mission of providing English-majored students with language proficiency training and specialized English courses, such as translation, literature and linguistics.

As China's economic and political status improves and international exchanges become more intensive, the demand for international talents is increasing, particularly, university graduates with composite talents, who are capable of experiencing professional socialization in an English-speaking working environment (Cheng, 2012; Zhang, 2015). Therefore, the importance of ESP teaching is highlighted. It is against this backdrop that ESP teaching was integrated into the College English curriculum (Xu \& Fan, 2017).

On the one hand, ESP teaching, combined with the individual specialty content, has been implemented to benefit students of non-English majors in certain Chinese universities. On the other hand, English-major programs adopted the following two reform measures. Firstly, Business English and Tourism English programs have been established to alleviate, to some extent, the current situation of the decline in the popularity of English major, which was caused by the reduced employment rate of English-major graduates in the job market (Qu, 2012). Secondly, traditional Englishlanguage programs, which capitalize on language and linguistic proficiency, ought to be embedded with knowledge in specific disciplines as well as ESP skills so as to prepare graduates to apply English language skills to particular professional contexts.

Located in a developing city in the central region of mainland China, the selected university aims to prepare graduates for the local job market to serve regional economic development via Industry-University-Research Projects. However, due to the underdeveloped local economy, especially the lack of large number of foreign trade companies in this area, limited opportunities are available for teachers and students. Therefore, ESP teachers' professional teaching and students' social practice are restrained accordingly. Deriving from this dilemma, it seems more necessary and urgent to explore the representative features of ESP teachers' identity, such as their confusions, struggles and even crises during the process of their professional identity construction.

\subsection{Participants}

The participants come from two administrative sectors in the selected university: Faulty of Foreign Languages (FFL) and International Education School (IES). They teach ESP courses to English-major students and non-English-major students, respectively. As the first author works in the same university with them, the participants all agreed to be interviewed as a token of colleague support.

The participants' educational backgrounds and teaching experiences varied substantially. All participants earned a Master degree in English linguistics or literature or translation, and received pre-service training of general teacher education before certified as qualified professional teachers. None of them had sufficient ESP learning experience.

They have a background in school teaching, or teacher education, and already know about the affective domain of learning: including values and attitudes, dispositions and behaviours. Moreover, sustainability is taught as an accepted professional value in their ESP disciplines, and they tend to deliberately or intuitively incorporate sustainability knowledge into their teaching approach.

It was in 2015 that both the Business English program under FFL and the General ESP courses under IES were established at this university. The teams consisted of several English teachers who had Bachelor degree in finance, science, law, and management, and teachers who had working experience in foreign trade companies. In expansion, the team recruited English teachers with qualification certificates, such as Business English Certificate, English Tourist Guide Certificate, and English Translator/Interpreter Certificate. Other in-service English teachers who showed interest in ESP teaching were also encouraged for involvement. They were offered training opportunities and were sent for professional enhancement of related subjects in other leading universities for a period of one or two semesters before teaching ESP in their own university. All ESP teachers are required to continue to develop discipline-related knowledge afterwards in the forms of online learning, academic conferences, vocational workshops, and so forth. The following table is an overview of the participants' demographics. 
Table 1. Biographic background of participants

\begin{tabular}{|c|c|c|c|c|c|c|c|}
\hline $\begin{array}{l}\text { Name } \\
\text { code }\end{array}$ & Gender & Position & $\begin{array}{l}\text { Years of } \\
\text { teaching }\end{array}$ & ESP courses taught & $\begin{array}{l}\text { University } \\
\text { affiliation }\end{array}$ & Educational background & $\begin{array}{c}\text { Work } \\
\text { experience }\end{array}$ \\
\hline A & Male & Professor & 25 & Busines Writing & $\begin{array}{l}\text { Faculty of Foreign } \\
\text { Languages (FFL) }\end{array}$ & $\begin{array}{l}\text { BA in English; } \\
\text { MA in Applied Linguistics; } \\
\text { Visiting Scholar abroad }\end{array}$ & No \\
\hline B & Male & Lecturer & 8 & E-commerce & FFL & $\begin{array}{l}\text { BA in English; } \\
\text { MA in Applied Linguistics }\end{array}$ & Yes \\
\hline $\mathrm{C}$ & Female & Lecturer & 15 & Business English & $\begin{array}{l}\text { International } \\
\text { Education School } \\
\text { (IES) }\end{array}$ & $\begin{array}{l}\text { BA in English for Science and } \\
\text { Technology; } \\
\text { MA in Applied Linguistics }\end{array}$ & No \\
\hline $\mathrm{D}$ & Male & $\begin{array}{l}\text { Asociate } \\
\text { professor }\end{array}$ & 13 & $\begin{array}{l}\text { Corporate } \\
\text { Management }\end{array}$ & IES & $\begin{array}{l}\text { BA in English; } \\
\text { MA in Translation; } \\
\text { Interpreter Certificate }\end{array}$ & Yes \\
\hline $\mathrm{E}$ & Female & Lecturer & 15 & $\begin{array}{l}\text { International Business } \\
\text { Law }\end{array}$ & FFL & $\begin{array}{l}\text { BA in Law; } \\
\text { MA in Applied Linguistics }\end{array}$ & No \\
\hline $\mathrm{F}$ & Female & $\begin{array}{l}\text { Associate } \\
\text { professor }\end{array}$ & 26 & $\begin{array}{l}\text { Teaching Chinese as a } \\
\text { Foreign Language }\end{array}$ & FFL & $\begin{array}{l}\text { BA in English; } \\
\text { MA in English Literature; } \\
\text { Visiting Scholar abroad; } \\
\text { Certificate of Chinese as a Foreign } \\
\text { Language Teacher; English Tour } \\
\text { Guide Certificate }\end{array}$ & Yes \\
\hline G & Male & Professor & 32 & Tourism Marketing & IES & $\begin{array}{l}\text { BA in English; } \\
\text { MA in Applied Linguistics; }\end{array}$ & No \\
\hline $\mathrm{H}$ & Female & Lecturer & 8 & $\begin{array}{l}\text { Translation of } \\
\text { Business Letters }\end{array}$ & FFL & $\begin{array}{l}\text { BA in English; } \\
\text { MA in Translation; } \\
\text { Interpreter Certificate } \\
\end{array}$ & Yes \\
\hline
\end{tabular}

All the ESP teachers had received their Bachelor's degree education in English programs with an exception of Teacher E, who studied Law as her undergraduate major. Five teachers obtained Master's degree in Applied Linguistics, two in Translation, and one in English Literature. None of them acquired postgraduate education in other disciplines related to their current ESP courses due to the recruitment restrictions from the university that only candidates of related English majors are eligible to apply for teaching positions in FFL and IES. Two teaches with senior professional titles (Teacher A and F) had the experiences of a visiting scholar abroad to at least two countries. Three teachers (Teacher D, $\mathrm{F}$ and $\mathrm{H}$ ) earned professional qualification certificates: both Teacher D and $\mathrm{H}$ have an Interpreter Certificates, while Teacher F has two certificates - Certificate of Chinese as a Foreign Language Teacher and English Tour Guide Certificate.

All participants had rich teaching experience for over ten years when interviewed except for Teacher B and $\mathrm{H}$ who had 8 years of teaching experience. All had been teaching general English courses before ESP concentration was introduced in 2015 across the university. Half of the eight teachers (Teacher B, D, F and H) played double roles of both an ESP teacher and an employee in local companies, providing services such as document translation and language consultation.

Five participants are affiliated with FFL (Faculty of Foreign Languages) while the remaining three belong to IES (International Education School). Owing to the fact that different departments have different teaching arrangements, and that the lack of public places such as an ESP Center fails to provide a platform for intellectual and academic exchanges, ESP teachers have to be scattered around the university teaching ESP courses to senior students (Year 3 and 4) of English major and non-English majors.

\subsection{Data Collection and Analysis}

This study conducted interviews to reduce participants' narratives focusing on their professional and personal experiences which play an essential role in shaping teachers' identity (Olsen, 2008). It employed the life history interview method that enables individual participant to relate their experiences, and enhance researchers' understanding of their accounts (Johnson \& Golombek, 2002; Gao, 2008). A series of open-ended questions was utilized to guide the interviews. During the interviews, new ideas or topics relevant to identity construction were welcome and encouraged. Since both the participants and the first author are native Chinese, the Putonghua (Standard Mandarin), as their first language, was used throughout the whole interviews to avoid communicative barriers. All interviews were audio- 
recorded and later transcribed verbatim. Relevant excerpts were selected and translated into English, which were under accuracy check by the second author.

Interview data analysis is comprised of two steps. Firstly, the life history of all participants was comprehensively acknowledged in a biographic approach (Gibbs, 2008). It avoids fragmentation and incompleteness caused by the lack of inherent causal relationships in a set of discrete pieces of narratives. Instead, it provides a holistic perspective into a comprehensive overview of each interviewee' s professional trajectory (Tao \& Gao, 2018). The baseline data for the study derived from individual mini-biography which was originated from each interview transcript concerned on the participant's professional path in a chronological order.

Secondly, the interview data was transcribed and translated in a paradigmatic approach (Erickson, 2004). It was organized into five categories in line with those of identity frames. Every transcript was under multiple searchers for contents that fit into any of the five categories. Following this, sub-themes that merge within each category were determined using content analysis techniques (Miles \& Huberman, 1994). Descriptive codes were generated from first coding before analytic codes were given to groups of similar codes during secondary coding. In addition, a teacher colleague was invited as a third person to code a selection of extracts. Upon comparison and discussion, an approximately $91 \%$ inter-rater reliability was reached.

\section{Results}

The analysis illustrated a holistic yet complex picture of ESP teachers' professional identity construction. A majority of participants conveyed feelings of pride and achievement due to their well-recognized significance to the career development of their students. Whereas, the constantly-occurring doubts and uncertainties in academic hierarchy greatly set up barriers to their professional identification. The following five frames of teacher identity would elaborate on certain aspects of teaches' identity struggles and complexities.

\subsection{Instructional Frame}

The instructional identity deals with the roles a teacher plays throughout classroom instruction (Pennington, 2014). Teaching about ESP subjects often challenges teacher due to high factual and professional complexity. The participants are mostly from either language or teaching background and had not received training on subject knowledge or teaching approaches, especially for ESP teaching before transforming into ESP teachers.

As teacher A, a professor, explained: "I strongly support multidisciplinary approaches to education, you know, to encourage students to solve a problem related to sustainable development with knowledge from different disciplines. But regrettably speaking, my hands are tied because I'm not capable of teaching in multidisciplinary contexts. You know, (senior) teachers of my age generally lack training based on ESD principles, and few of us got overseas professional development experiences. So I just do what I do best - to follow the textbook".

Apparently, they are constrained by comparatively narrow international views and insufficient knowledge in subject area and low self-perceived competence towards ESD. And consequently, they are not able to author their identity due to lack of control over teaching contents or materials.

Furthermore, the participants found themselves to be diffident in classroom to develop the students' hands-on skills due to their own limited first-hand professional work experiences in industry. For example, teacher B, who is a young lecturer, described his practice-based classroom instruction to be like:

"I conduct student-centred teaching approach by organizing class activities such as group discussion and individual presentation, but I couldn't perform the role of a facilitator in ESP teaching because I don't have any professional work experiences to enable myself to do so. All I know is theory. So what I did is just comment generally on their grammatical errors and presentation skills instead."

Teacher B also emphasized the key role of work experiences in ESP teaching. However, when asked about the reasons for his decision not to transform to a double-professionally-titled teacher, teacher B listed them into two aspects: the push factor and pull factor.

"From the perspective of push factor, I think it is unreasonable and even unfair of school to establish evaluation criteria with major focus on academic achievements rather than social practice. It tremendously diminishes my motivation to engage myself in working part-time at companies outside the campus. As for the pull factor, I heard companies are reluctant to offer you a real chance to learn in practice because of your discontinuous and unsustained involvement in the workplace. Another important reason is that the company I was going to work for is a poor example of sustainable development. As a result, it seems difficulty for me to link theories to practical actions".

Teacher B's reluctance to transformative changes resulted from a multitude of internal and external pressures. The fact 
that the ESP teachers fail to rely on their professional qualification and social practice experiences to instruct their teaching would decrease the sense of empowerment, hence greatly impact the instructional component of their teacher identity.

\subsection{Disciplinary Frame}

ESP teachers' disciplinary identity is primarily connected to a specific field or discipline (Pennington, 2014). It is revealed that the majority of participants found it far-fetched to claim themselves to be the experts of a specific field, about which they are currently learning and teaching. This subject-specific micro-level influences restrain teachers from developing a sense of identification as a qualified ESP teacher. Furthermore, the generally-acknowledged perceptions that ESP is denied as an academic discipline and the frequently-misconceived idea that sustainability education is no more than a name together undermine ESP teachers' identity negotiation at the macro level.

Teacher $\mathrm{C}$, a lecturer, gave his understandings of being an ESP teacher.

"Many of us think that being an ESP teacher just means taking up a special extra course. And the integration of ESD into our syllabus just means one or two chapters covering the basic concepts and principles of sustainable development. All you need to do is buy some books and do more lesson planning to equip yourself as a generalist in this subject because you simply can't compete with the students and professors in this discipline. I constantly feel myself as an outsider. Other language teachers would consider themselves lucky if they don't have to teach ESP courses. After all, it is not an academic discipline as linguistics, literature or translation."

Teacher C's interpretation of ESP teachers' academic status shows the frustration to negotiate and balance their sense of content area expert and generalist. It is echoed with the statements that ESP teachers may be faced with embarrassment when involving with students who are more resourceful in terms of pertinent professional knowledge and skepticism when dealing with specialist professors who are doubtful of their qualifications (Tsou \& Chen, 2014). Despite this, the non-academically recognized status of ESP teaching may all the more confuse their disciplinary identities (Clarke, 2008; Tsui, 2007).

The ESP teachers' identity development is further unassured by inadequate support such as an officially-announced Teaching and Research Centre in the university, for such place would establish a community within which colleagues could share what they learned and achieved (Biasutti et al., 2017). Teacher D described that "As we don't have a fixed place to go to, ESP teachers mostly make do with it by temporarily staying at different academic units dispersedly. We are like scattered sheep with no leader and no sense of direction. And we are more like a loner who works independently".

From the data, it is evident that teachers' sense of relatedness and belonging is hardly met. It exerts immediate effects on their professional growth in terms of both teaching and research. Consequently, it would impede the formation of their disciplinary identity.

\subsection{Professional Frame}

Teachers' beliefs, knowledge and practices of a specific field constitute the professional frame of their identity, which evolves through their own perceptions and involvements in teaching and research activities as well as social networks over the course of the teaching career (Pennington, 2014). As for ESP teachers, recognition of their dual professional expertise are being challenged or even questioned by both parties of specialist professors of a specific discipline and general language teachers in the universities, not to mention their idea of sustainability education.

It is uncovered from the interview data that some participants developed their ESP career independently and maintained scarce collaboration with specialist professors of a specific discipline. Teacher E, who achieved a bachelor's degree in law before pursuing her master degree of translation, distinguished herself as an ESP teacher to law students. And yet, she still found it difficult to put herself on an equal basis with law professors in both theoretical and practical terms.

"I really don't appreciate the feeling of being treated as someone who is next to an outsider of this field. And sadly I am not alone. Other ESP teachers, who teach Journalism, Management, Business, etc., share similar feelings."

If their ESP teacher identity seems to be under threat, then Teacher F's narrative would put their general language teacher identity independent of that of those who remain to be a mere language teacher.

"We have little interaction with colleagues from other branches such as Translation Studies or Linguistic Studies, because we are strangers in terms of research interests and teaching priority. They don't take sustainable development into account because (they think) it is a matter exclusive to science and engineering. Besides, there is only a small number of us and we feel excluded in the department." 
Teacher $\mathrm{E}$ and $\mathrm{F}$ failed to see themselves as competent and indispensable facilitator in students' learning of both subject knowledge in the ESP lessons and English language, let alone of as a role model to promote ESD in the university, where sustainability is neither cherished nor recognized as a disciplinary trait (Dawe et al., 2005). It shows the ways teachers negotiate and balance their sense of self between authority and vulnerability. The reality that ESP teachers retrieve to scarce contact with other teachers could be justified by the perceived power relation between the mainstream and the others. This alienation elicits an implicit boundary among groups of teachers in the university. It creates barriers for ESP teachers to form professional identities and assert themselves to be ESP teachers in the institution.

\subsection{Vocational Frame}

The vocational frame deals with the affective dimension of teacher identity, which entails a teacher's attachment and commitment to teaching vocation (Pennington, 2014). In other words, teachers' sense of vocational identity relies on how successful they see themselves during teaching activities and the emotional responses it evokes. A reoccurring theme of the relevant narratives appears to circle the feelings of frustration and self-doubt emerged within a classroom context (Nichols et al., 2016) as well as within community engagement practice (Perera et al., 2018; Tang et al., 2018).

In language-teaching classroom, Teacher $\mathrm{G}$ admitted that she has been adjusting to a new teacher role. "Nowadays, students prefer independent learning, especially language-majored students. They are more eager to improve their language skills and learning strategies with the help of learning websites and applications on their smart devices where authentic and updated materials are provided in multiple modes, such as text, audio, and visual forms. And they sometimes show very little interest in sustainable development. (Therefore) I feel less needed as a teacher. I am still looking for a point to keep balance emotionally".

Students' lack of interest in ESD could be an essential cause for teachers' frustration in class (Murel et al., 2015). While lack of constructive and effective involvement in community engagement inevitably leads to teachers' doubts in their ability and willingness to gain practical experience outside of academia.

During the process of local community engagement, Teacher $\mathrm{H}$, who maintained a continuous involvement in university-company partnership as a translator of business documents, explained the boundary and barrier in their collaboration.

"I take up a part-time job in a company, but I'm not in charge of anything or be part of any decision-making process. I only work as a translator. So I have limited first-hand access to core business such as business contracts, which are considered as critical business secrets, and thus highly confidential. Therefore, it is not easy for me to turn into a professional in this industry due to the role I play within the company. Consequently, I don't feel confident in facilitating students to integrate some form of community engagement in their studies. The best I could do is provide students with test-taking skills for their industry certifications, such as BEC (Business English Certificate), Accounting Certificate, and Tour Guide Certificate, etc."

In addition to the above extracts, several other teachers also explained how such frustrating experiences related to their emotionally-suggestive reactions that would put their self-perceptions into question and undermine their sense of selfworth as an ESP teacher as well as an ESD practitioner.

\subsection{Economic Frame}

It involves teacher identity with a sense of achievement in terms of both economic and academic position in the field (Pennington, 2014). The participants' narratives suggested that their sense of academic achievement was suppressed due to intrinsic and extrinsic reasons.

Teacher E, as the representative female teacher in the group, complained about the lack of time and energy for research work.

"I have many teaching hours every week. Besides, preparing for lessons occupies quite a proportion of my time. If I happen to take up one or two new courses, it would get crazy. I'm either teaching or lesson planning, leaving me no time to do research. What's worse, family members also need my attention and care, especially grandparents and kids. It seems like that family is the center of my personal life and it feels luxurious to talk about research. All I could focus right now is the quality of my teaching, (and) I put in efforts on improving students' critical thinking ability and raising their sustainable awareness".

Teacher E provided intrinsic reasons for her fruitless research by referring to the practical difficulties in real life. Her case represents a majority of teachers in higher education, especially female teachers with family responsibilities that constrain their academic career development (Wang, 2015). Yet their passion for promoting the critical thinking abilities of their students should be encouraged, furthermore, the inclusion of sustainability education in their related 
teaching activities should be recognized and rewarded (Shephard, 2015).

Meanwhile, for those who have not suspended their research endeavors, their academic careers are further hindered due to the fact that ESP research has been marginalized in the traditional language department where linguists and literature scholars have dominated mainstream language research (Tao \& Gao, 2018). Three participants (Teacher A, $\mathrm{B}, \mathrm{E})$ complained about the unfairness of promotion criteria which recognize top journal publications only on foreign language studies. For example, Teacher B states:

"I published two research articles this year, and one of them appeared in a top journal. Unfortunately, this journal couldn't guarantee my promotion because it is an Education journal, not about Language Pedagogy, therefore, its credit somehow got devalued".

The above mentioned are the extrinsic factors that frustrate ESP teachers in their way of promotion. The academic requirement seems so far-reaching and impossible to meet up that it takes academic staff away from their substantive roles of teaching and research.

In contrast, several teachers' community engagement shows the way teachers negotiate and balance their sense of self in the dilemma between institutional promotion and financial rewards to build up their economic identity (Pennington, 2014). Teacher $\mathrm{E}$ and Teacher $\mathrm{H}$ have been providing their professional expertise of legal consultancy and business letter translation for local law firms and companies. As noted by Teacher E:

"Working for companies as a legal counsel makes me feel appreciated as a professional. It feels like I'm on the path of contributing to sustainability as an educated and responsible individual. And I am also happy to get paid accordingly. I just wish for more opportunities like this in this city".

As disclosed above, involvements outside campus offer ESP teachers a fresh environment where their ESP expertise and sustainable competence are valued and rewarded. It enables teachers to engage in fulfilling their social responsibilities and transcend the institutional limitations. Eventually, this benefits the process of their ESP teacher identity construction in a broader socio-economic context.

\section{Discussion}

This study investigates the constraints in developing ESP teachers' identity in the context of sustainability education. It depicts a holistic yet complex picture of the identity construction of ESP teachers at a Chinese university. It also reflects the situation of ESP teachers elsewhere in the country. The life-history narratives uncover that ESP teachers, in their endeavor to promote ESD, have encountered discouraging experiences in their teaching and research practice regarding sustainability principles with academic colleagues, students and institutional administrators. They not only reflected and transformed their instructional identity in the classroom, but also other frames of identity within the institutional and socio-economic contexts.

The participants' narratives highlight the significance of professional qualification in subject knowledge and social practice experience in shaping their instructional identity. Since ESD teaching is integrated into their instructional orientations, it may impact the practices of individual ESP teachers and alter their instructional identity as they master a new teaching concept with diversified expertise. It contributes to their identity development in their faculty by distinguishing themselves from other teachers. On the contrary, a lack of confidence in claiming themselves to be the experts in a specific field undermines ESP teachers' disciplinary identity. Furthermore, the reality that ESP does not have a recognized disciplinary status (Pennington, 2014; Tao \& Gao, 2018) and that sustainability is not considered as a disciplinary trait (Dawe et al., 2004) strongly impedes the construction of teachers' disciplinary identity in teaching and research as well. Based on their accounts, a physical Teaching and Research Institution representing recognized academic disciplines would confer great power and academic legitimacy to ESP teachers in enhancing their sense of belonging and connection and building their disciplinary status in academia.

A teacher's professional identity incorporates connections to various groups of colleagues in the institutional context (Pennington, 2014). Collegial interactions provide professional development opportunities for teachers to disseminate research, share expertise, and stimulate continued learning and reflective practice (Pennington, 2014). It weaves a valuable network of influences under which teachers' interpretation and negotiation of their professional identities evolve. Unfortunately, ESP teachers in our study uncover a fact that scarce interpersonal interaction and little professional collaboration take place between them and the mainstreamed groups of general English language teachers and those of professors from specific disciplines. The marginalization and alienation in the power relation produce obstacles and barriers for ESP teachers to form their professional identities.

Teachers' vocational identification encompasses teacher commitment and attachment to the students and to the teaching 
job (Pennington, 2014). Being in a helping profession, teachers are dedicated to seeking intrinsic satisfaction by means of fostering professional qualities and sustainable competencies in their graduates. The frustration and self-doubt that ESP teachers have experienced due to students' lack of interest and unsuccessful community engagement generally diminish their identification with ESP or ESD practice as a vocation (Morris \& King, 2019).

Teachers' academic and economic position in the field relies on their publication of journal articles and books. It brings about a high level of satisfaction and self-image as well as tangible rewards in terms of benefits and promotion. Barriers and challenges either from work-life balance or academic publication evaluation system have exerted a negative impact on teachers' identity as an ESP educator and a sustainability education practitioner. However, it is important for ESP teachers to be purposeful about integrating the concept of sustainability into their teaching content, particularly the relevant attitude and values, to foster sustainability consciousness of their students. When teachers feel appreciated and valued for their disciplinary expertise and sustainable competencies beyond the institutional context and are adequately compensated in terms of external rewards, their economic identity resumes to a large extent on a broader social scale.

Our findings show that the identity construction of ESP teachers is mediated by institutional and socio-economic contexts. Even though each identity frame contains distinctive features that outline the ways in which teachers construct their identity, altogether the five frames interplay with each other in shaping how teacher regard and position themselves in the university. Meanwhile, continuous community engagement not only benefits ESP teaching but also supports the applicability and significance of ESD practice. More importantly, such involvement constitutes a underpinning foundation for ESP teacher identity development.

\section{Conclusion}

The aim of this study is to promote teacher professional development in the area of ESD practice in higher education institutions by investigating the construction of ESP teacher identity and identifying the sources of constraints in this process. It is found that elements such as teachers' professional incompetence, low academic status, lack of professional interactions with colleagues, professional insecurity, absence of teaching autonomy and inadequate economic compensations are regarded to have negative impact on ESP teacher identity. In addition, the construction of teacher identity is a constantly-evolving and ever-changing process, and it continually shapes and even redefines a teachers' identity at any given time (Sachs, 2005). Therefore, it is essential that ESP teachers' identities are acknowledged and valued to promote the implementation of ESD in higher education institutions.

This study provides a new and innovative perspective into the issue of ESD development in higher education. It draws attention of institutional administrators and policy-makers to put emphasis on such complex yet important issue as teacher identity embedded in the advancement of ESD. By incorporating sustainability into its administration and policies, universities will improve its capacity to provide substantial opportunities for ESP teachers' professional development and to help society address future challenges of sustainable development in a changing world.

This study also could be the basis for future proposals elsewhere. Since the identity construction of ESP teachers shows unique features in different contexts. For instance, the geographical location of the university and its educational orientation in either academic research or social practice constitute two major influencing factors of teacher identity formation. It would help build a holistic view on teacher identity to apply this study to research-oriented universities in developed cities in China, where sustainability education has received early and continuous attention from teaching and administrative staff. Moreover, further research studies could focus on the impact of teachers identity on educational reform (ESD in particular) from a longitudinal perspective as the identity construction is a long-term process full of dynamic changes. A follow-up study could examine the potential changes that this research induced in the participants' professional identity development. Eventually, future study on teacher identity needs to pay close attention to the ways teachers experience, express, and regulate sustainable education practice as they navigate their career pathway.

\section{Acknowledgements}

This research was funded by Shanxi Scholarship Council of China and Yuncheng University under "Research Project for Overseas Scholars" (2016-107), "Special Project of Teaching Reform Research" (JGX 07) and "Research Project of Yuncheng University” (CY-2020013).

\section{References}

Barth, M., \& Rieckmann, M. (2012). Academic staff development as a catalyst for curriculum change towards education for sustainable development: An output perspective. Journal of Cleaner Production, 26, 28-36. https://doi.org/10.1016/j.jclepro.2011.12.011 
Barth, M., Michelsen, G., Rieckmann, M., \& Thomas, I. (2016). Routledge handbook of higher education for sustainable development. London: Routledge.

Basturkmen, H. (2014). Ideas and options in English for specific purposes. London: Routledge. https://doi.org/10.4324/9781410617040

Beauchamp, C., \& Thomas, L. (2009). Understanding teacher identity: An overview of issues in the literature and implications for teacher education. Cambridge Journal of Education, 39(2), 175-189. https://doi.org/10.1080/03057640902902252

Beijaard, D., Meijer, P. C., \& Verloop, N. (2004). Reconsidering research on teachers' professional identity. Teaching \& Teacher Education, 20(2), 107-128. https://doi.org/10.1016/j.tate.2003.07.001

Biasutti, M., Makrakis, V., Concina, E., \& Frate, S. (2017). Educating academic staff to reorient curricula in ESD. International Journal of Sustainability in Higher Education, 19(1), 179-196. https://doi.org/10.1108/IJSHE-11-2016-0214

Buchanan, R. (2015). Teacher identity and agency in an era of accountability. Teachers and Teaching, 21(6), 700-719. https://doi.org/10.1080/13540602.2015.1044329

Cai, J. G. (2015). Internationalization and Englishnization: Language policy is a choice. Technology Enhanced Foreign Language Education, (163), 3-9.

Cheng, L. (2012). English immersion schools in China: Evidence from students and teachers. Journal of Multilingual \& Multicultural Development, 33(4), 379-391. https://doi.org/10.1080/01434632.2012.661436

Clarke, M. (2008). Language teacher identities: Co-constructing discourse and community. Clevedon: Multilingual Matters. https://doi.org/10.21832/9781847690838

Cotton, D. R. E., Warren, M. F., Maiboroda, O., \& Bailey, I. (2007). Sustainable development, higher education and pedagogy: a study of lecturers' beliefs and attitudes. Environmental Education Research, 13(5), 579-597. https://doi.org/10.1080/13504620701659061

Cross, D. I., \& Hong, J. Y. (2009). Beliefs and professional identity: Critical constructs in examining the impact of reform on the emotional experiences of teachers: Advances in teacher emotion research. US: Springer. https://doi.org/10.1007/978-1-4419-0564-2_14

Dawe, G. F. M., Vetter, A., \& Martin, S. (2004). An overview of ecological footprinting and other tools and their application to the development of sustainability process. International Journal of Sustainability in Higher Education, 5(4), 340-371. https://doi.org/10.1108/14676370410561063

Day, C., Kington, A., Stobart, G., \& Sammons, P. (2013). The personal and professional selves of teachers: Stable and unstable identities. British Educational Research Journal, 32(4), 601-616. https://doi.org/10.1080/01411920600775316

Day, C., Elliot, B., \& Kington, A. (2005). Reform, standards and teacher identity: Challenges of sustaining commitment. Teaching and Teacher Education, 21(5), 563-577. https://doi.org/10.1016/j.tate.2005.03.001

Erickson, F. (2004). Demystifying data construction and analysis. Anthropology \& Education Quarterly, 35(4), 4486493. https://doi.org/10.1525/aeq.2004.35.4.486

Filho, W. L. (2010). Teaching sustainable development at university level: current trends and future needs. Journal of Baltic Science Education, 9(4), 273-284.

Filho, W. L. (2015). Education for sustainable development in higher education: Reviewing needs. In Leal Filho, W.L. (Ed.), Transformative approaches to sustainable development at universities. Switzerland: Springer.

Filho, W. L., Brandli, L. L., Becker, D., Skanavis, C., Kounani, A., \& Sardi, C., et al. (2018). Sustainable development policies as indicators and pre-conditions for sustainability efforts at universities: Fact or fiction? International Journal of Sustainability in Higher Education, 19(14), 86-113. https://doi.org/10.1108/IJSHE-01-2017-0002

Gao, X. (2008). Teachers' professional vulnerability and cultural tradition: A Chinese paradox. Teaching and Teacher Education, 24(1), 154-165. https://doi.org/10.1016/j.tate.2006.11.011

Gibbs, C. R. (2008). Analyzing qualitative data. London: SAGE. https://doi.org/10.4135/9781849208574

Granados Sanchez, J., \& Fredi, J. (2012). Higher educations commitment to sustainability: From understanding to action. International Journal of Sustainability in Higher Education, (3), 167-169. 
Grosse, C. U., \& Voght, G. M. (2012). The continuing evolution of language for specific purposes. The Modern Language Journal, 96, 190-202. https://doi.org/10.1111/j.1540-4781.2012.01304.x

Grosseck, G., Tiru, L., \& Bran, R. (2019). Education for sustainable development: Evolution and perspectives. Sustainability, 11(21), 6136-6148. https://doi.org/10.3390/su11216136

Gu, M., \& Benson, P. (2015). The formation of English teacher identities: A cross-cultural investigation. Language Teaching Research, 19(2), 187-206. https://doi.org/ 10.1177/1362168814541725

Johnson, K. E. (2006). The sociocultural turn and its challenges for second language teacher education. Tesol Quarterly, 40(1), 235-257. https://doi.org/10.2307/40264518

Johnson, K. E., \& Golombek, P. R. (2002). Teachers' narrative inquiry as professional development. Cambridge: Cambridge University Press.

Jones, R. B. M. (2018). Widening interdisciplinary sustainability education. Tempo, 59(231), $72-80$. https://doi.org/10.1017/S004029820524007X

Kalsoom Q., Khanam, A., \& Quraishi, U. (2017). Sustainability consciousness of pre-service teachers in Pakistan. International Journal of Sustainability in Higher Education, 18(7), 1090-1107. https://doi.org/10.1108/IJSHE-11-2016-0218

Kishita, Y., Uwasu, M., Hara, K., Kuroda, M., Takeda, H., Umeda, Y., \& Shimoda, Y. (2018). Toward designing sustainability education programs: A survey of master's programs through semi-structured interviews. Sustainability Science, 13(4), 953-972. https://doi.org/10.1108/IJSHE-11-2016-0218

Kubanyiova, M., \& Crookes, G. (2016). Re-envisioning the roles, tasks, and contributions of language teachers in the multilingual era of language education research and practice. Modern Language Journal, 100(1), 117-132. https://doi.org/ 10.1111/modl.12304

Michalos, A. C. (2014). Index of attitudes favorable toward sustainable development. Netherlands: Springer. https://doi.org/10.1007/978-94-007-0753-5_3688

Miles, M. B., \& Huberman, A. M. (1994). Qualitative data analysis: An expanded sourcebook. Thousand Oaks, California: SAGE.

Minguet, A. P., Martinez-Agut, M. P., Palacios, B., Pinero, A., \& Ull, M.A. (2011). Introducing sustainability into university curricula: An indicator and baseline survey of the views of university teachers at the University of Valencia. Environmental Education Research, 17(2), 145-166. https://doi.org/10.1080/13504622.2010.502590

Mirjam Braßler. (2016). Interdisciplinary problem-based learning: A student-centered pedagogy to teach social sustainable development in higher education. London: Springer International Publishing. https://doi.org/10.1007/978-3-319-32928-4_17

Morris, S., \& King, J. (2019). Teacher frustration and emotion regulation in university language teaching. Chinese Journal of Applied Linguistics, 41(4), 433-452. https://doi.org/10.1515/cjal-2018-0032

Mulder, K. F., Ferrer, D., Segalas Coral, J., Kordas, O., Nikiforovich, E., \& Pereverza, K. (2015). Motivating students and lecturers for education in sustainable development. International Journal of Sustainability in Higher Education, 16(3), 385-401. https://doi.org/10.1108/IJSHE-03-2014-0033

Nichols, S. L., Schutz, P. A., Rodgers, K., \& Bilica, K. (2016). Early career teachers' emotion and emerging teacher identities. Teachers and Teaching, 23(4), 406-421. https://doi.org/10.1080/13540602.2016.1211099

Olsen, B. (2008). Teaching what they learn, learning what they live: How teachers' personal histories shape their professional development. Ablingdon: Routledge.

Olsson, D., Gericke, N., \& Rundgren, S. N. C. (2015). The effect of implementation of education for sustainable development in Swedish compulsory schools: Assessing pupils' sustainability consciousness. Environmental Education Research, 22(2), 1-27. https://doi.org/10.1080/13504622.2015.1005057

Pappas, E., Pierrakos, O., \& Nagel, R. (2013). Using Bloom's Taxonomy to teach sustainability in multiple contexts. Journal of Cleaner Production, 48, 54-64. https://doi.org/10.1016/j.jclepro.2012.09.039

Pennington, M. C. (2014). Teacher identity in TESOL: A frames perspective. In Y. L. Cheung, S. B. Said, \& P. Kwanghyun (Ed.), Advances and current trends in language teacher identity research (pp. 16-30). Abington: Routledge. https://doi.org/10.4324/9781315775135-2 
Perera, H. N., Granziera, H., \& Mcilveen, P. (2018). Profiles of teacher personality and relations with teacher selfefficacy, work engagement, and job satisfaction. Personality and Individual Differences, 120, 171-178. https://doi.org/10.1016/j.paid.2017.08.034

Pompeii, B., Chiu, Y. W., Neill, D., Braun, D., Fiegel, G., Oulton, R., \& Singh, K. (2019). Identifying and overcoming barriers to integrating sustainability across the curriculum at a teaching-oriented university. Sustainability, 11(9), 2652. https://doi.org/10.3390/su11092652

Qu, W. (2012). 'Practical' English and the crisis of English studies. English Today, 28(3), 15-20. https://doi.org/10.1017/S0266078412000247

Sachs, J. (2005). Teacher education and the development of professional identity: Learning to be a teacher. In Connecting policy and practice: Challenges for teaching and learning in schools and universities (pp. 5-21). New York, London: Routledge.

Schutz, P. A., Cross, D. I., Hong, J. Y., \& Osbon, J. N. (2007). Teacher identities, beliefs, and goals related to emotions in the classroom. California: Elsevier Inc. https://doi.org/10.1016/B978-012372545-5/50014-9

Shephard, K. (2015). Higher education for sustainable development. Basingstoke, UK: Palgrave Macmillan. https://doi.org/10.1057/9781137548412

Simon-Maeda, A. (2004). The complex construction of professional identities: Female EFL educators in Japan speak out. TESOL Quarterly, 38(3), 405-436. https://doi.org/10.2307/3588347

Sterling, S., \& Witham, H. (2008). Pushing the boundaries: The work of the higher education academy's ESD project. Environmental Education Research, 14(4), 399-412. https://doi.org/10.1080/13504620802340918

Tang, Y. He, W., Liu, L., \& Li, Q. (2018). Beyond the paycheck: Chinese rural teacher well-being and the impact of professional learning and local community engagement. Teachers and Teaching, 24(7), 825-839. https://doi.org/10.1080/13540602.2018.1470972

Tao, J., \& Gao, X. (2018). Identity constructions of ESP teachers in a Chinese university. English for Specific Purposes, 49, 1-13. https://doi.org/10.1016/j.esp.2017.09.003

Tao. J., \& Gao. X. (2017). Teacher agency and identity commitment in curricular reform. Teaching and Teacher Education, 63, 346-355. https://doi.org/10.1016/j.tate.2017.01.010

Tsou, W., \& Chen, F. (2014). ESP program evaluation framework: Description and application to a Taiwanese university ESP program. English for Specific Purposes, 33, 39-53. https://doi.org/10.1016/j.esp.2013.07.008

Tsui, A. B. (2007). Complexities of identity formation: A narrative inquiry of an EFL teacher. TESOL Quarterly, 41(4), 657-680. https://doi.org/10.1002/j.1545-7249.2007.tb00098.x

Tweedie M.G., \& Johnson R.C. (2018). Listening instruction for ESP: Exploring nursing education where English is a lingua franca. In Burns A., Siegel J. (Ed.), International perspectives on teaching the four skills in ELT (pp. 65-77). Cham: Palgrave Macmillan. https://doi.org/10.1007/978-3-319-63444-9 5

UN, United Nations. (2002). Report of the World Summit on Sustainable Development, Johannesburg. Available at: http://www.johannesburgsummit.org/html/documents/ummit-docs/13102_wssd_report_reissued.pdf. Accessed 20 October 2020.

United Nations Educational, Scientific, and Cultural Organization (UNESCO). (2014). UNESCO roadmap for implementing the Global Action Programme on Education for Sustainable Development. France: UNESCO.

Varga, A., Kószó, M. F. Z., Mayer, M., \& Sleurs, W. (2007). Developing teacher competences for education for sustainable development through reflection: The environment and school initiatives approach. Journal of Education for teaching, 33(2), 241-256. https://doi.org/10.1080/02607470701259564

Varghese, M., Morgan, B., Johnston, B., \& Johnson, K. A. (2005). Theorizing language teacher identity: Three perspectives and beyond. Journal of language, Identity, and Education, 4(1), 21-44. https://doi.org/10.1207/s15327701jlie0401_2

Wang, W. (2015). Teaching English as an international language in China: Investigating Chinese university teachers' and learners' attitude towards China English. System, 53, 60-72. https://doi.org/10.1016/j.system.2015.06.008

Warburton, K. (2003). Deep learning and education for sustainability. International Journal of Sustainability in Higher Education, 4(1), 44-56. https://doi.org/10.1108/14676370310455332 
Whitsed, C., \& Volet, S. (2013). Positioning foreign English language teachers in the Japanese university context. Teachers and teaching, 19(6), 717-735. https://doi.org/10.1080/13540602.2013.827459

Xu, J., \& Fan, Y. (2017). The evolution of the college English curriculum in China (1985-2015): Changes, trends and conflicts. Language Policy, 16, 267-289. https://doi.org/10.1007/s10993-016-9407-1

Zhang, L. (2015). An empirical study on the intelligibility of spoken by Chinese university students. Chinese Journal of Applied Linguistics, 01, 36-54. https://doi.org/10.1007/s10993-016-9407-1

Zhang, X. Y. (2019). Construction of teachers' educational ability for sustainable development. Journal of Beijing Institute of Education, 33(3), 41-47.

\section{Copyrights}

Copyright for this article is retained by the author(s), with first publication rights granted to the journal.

This is an open-access article distributed under the terms and conditions of the Creative Commons Attribution license (http://creativecommons.org/licenses/by/4.0/). 